\title{
Examination of the possibility of transborder pollution in the days with registered excee- dances of pollutant dust in the city of Ruse, Bulgaria
}

\author{
Antoaneta Stefanova ${ }^{1, *}$, Ivanka Zheleva $^{1}$, Margarita Filipova ${ }^{1,}$ and Irina Tsvetkova $^{1}$ \\ ${ }^{1}$ Ruse University, 8 Studentska Str., 7017, Ruse, Bulgaria
}

\begin{abstract}
The presented study of the PM10 concentrations in the atmosphere ground layer emitted from industrial sources in the Industrial zone in the city of Ruse in the days with exceedances for this pollutant is aimed to determining the possibility of cross-border BG-RO PM10 contamination. Climatic conditions measured in these days with PM10 exceedances in January 2017 are also taken into account in Jet Gauss model and in the Langrageo-statistical approach for describing the turbulent diffusion. The results show that the PM10 pollutant from the investigated sources in industrial zone in Ruse is reaching the territory of Republic of Romania with low concentrations and have no potential for impact on air quality in the cross-border area.
\end{abstract}

\section{Introduction}

The Municipality of Ruse is one of the municipalities in Bulgaria designated as an area for assessment and management of ambient air quality for dust contaminants. Annually during the winter seasons exceedance of the norms for the protection of human health for pollutant PM10 (particulate matter with a diameter between 2.5 and $10 \mu \mathrm{m}$ ) is registered in the "Vazrazhdane" Automatic Measuring Station (AMS) [7]. The sources of dust from the territory of Ruse are industry, transport and domestic heating. A significant part of the industrial sources in the city of Rousse is concentrated in the territory of the Industrial zone, Ruse (see Fig.1).

The main objective of the present study is to analyse the probability of cross-border pollution of the ambient air as a result of the simultaneous operation of industrial sources concentrated on the territory of Industrial zone in the town of Ruse during January 2017 period of registered exceedances of the PM10 norms for protection of human health [7].

Subjects of the study are:

- Analysis of weather conditions (temperature, wind rose, prevailing wind direction and speed) in the days of January 2017 with recorded PM10 exceedances.

- Identification of the organized sources of dust on the territory of industrial zone of Ruse;

- Computer simulation to calculate the maximum ground concentrations of PM10 pollutant emitted from the industrial zone of Ruse and the distances to which PM10 pollutant is disseminated;

- Analysis of the dust ground concentration reaching the territory of the Republic of Romania and the possibility of their influence on the air quality in the cross-border area.

*Corresponding author: astefanova@uni-ruse.bg 
The territory of the industrial zone - Ruse is located along the Danube riverbank. Numerous industries from the chemical, manufacturing, machine-building and other sectors are concentrated on its territory (see Fig.1).

\section{Materials and Methods}

The necessary information for the study is provided through:

- Available information from the official website of the competent authority - Regional Inspectorate of Environment and Water (RIEW) - Ruse [1],

- Information provided by the Regional Inspectorate of Environment and Water - Ruse under the Access to Public Information Act $[2,4]$,

- Verification of data on industrial sources through meetings and contacts with the legal representatives of entities operating the identified sources of dust emissions from the investigated territory [3]

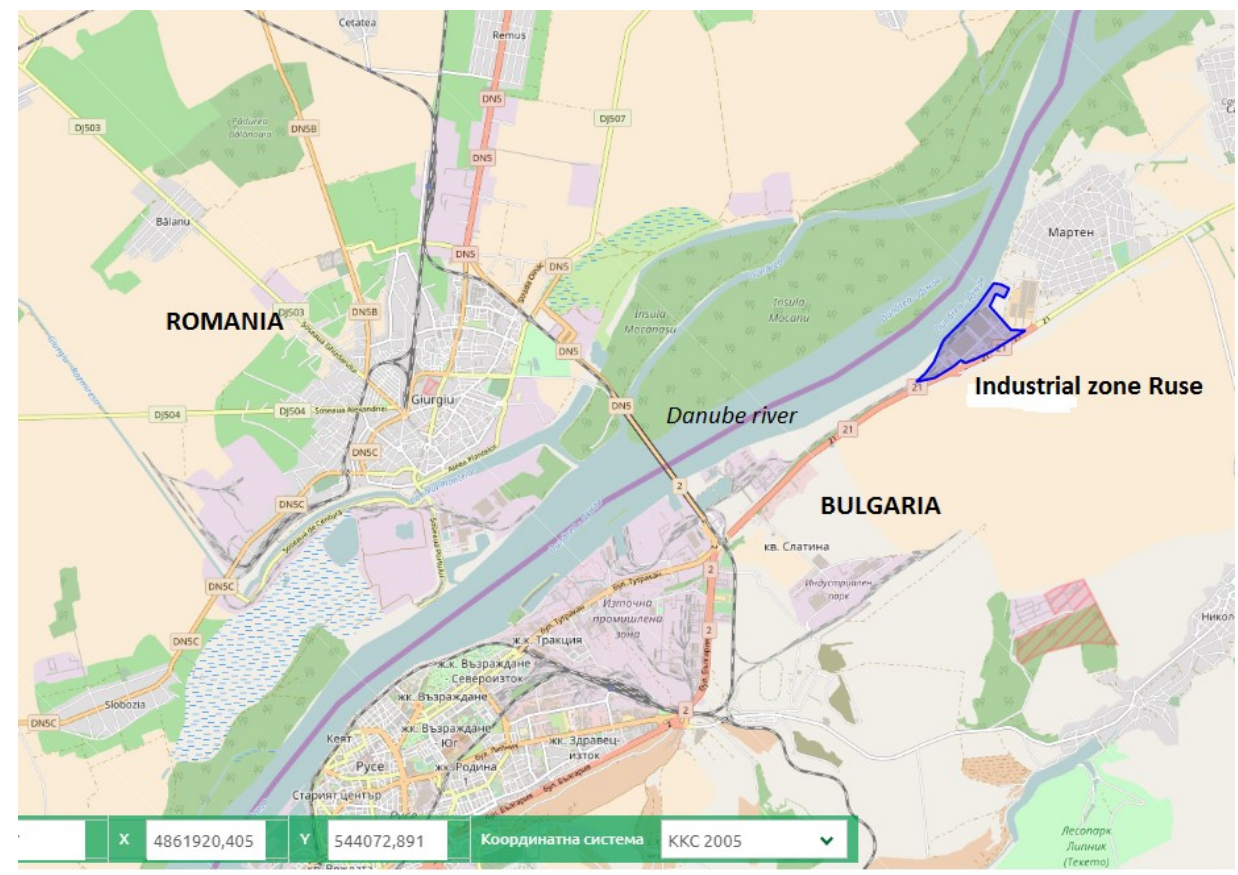

Fig.1. Map of industrial zone of Ruse [5].

For mathematical simulations PLUME software was used. This software is made according the Methodology for calculating the leakage height, dispersion and expected concentrations of pollutants in the ground atmospheric layer from 25 February 1998. It is officially adopted by the Bulgarian Ministry of Environment and Waters, by the Ministry of Regional Development and Public Works and by the Ministry of Health [6].

The software used is based on a Gauss jet gas model and on the Lagrangian-statistical approach for describing the processes of turbulent diffusion. The methodology and the software allow the following problems related to our study to be solved:

- Calculation of the expected concentrations of the harmful substances (PM10) in the ground layer of the atmosphere; 
- Calculation of the average concentrations per specified wind rose for the relevant averaging period. In our case we use daily average.

\section{Results and Discussions}

\subsection{Analysis of meteorological conditions in days with registered PM10 exceedances}

\subsubsection{Days with registered PM10 exceedances in January 2017}

Table 1. Days with registered exceedances by pollutant PM10 by automatic measuring station "Vazrazhdane" for January 2017.

\begin{tabular}{|c|c|c|}
\hline \multirow{2}{*}{ Date } & $\begin{array}{c}\text { Measured } \\
\text { concentration of } \\
\text { PM10 }\end{array}$ & $\begin{array}{c}\text { Exceedance of } \\
\text { the daily limit } \\
\text { for PM10 }\end{array}$ \\
\cline { 2 - 3 }$\left[\begin{array}{c}\left.\mathbf{\mu g} / \mathbf{m}^{\mathbf{3}}\right] \\
\mathbf{( 5 0} \boldsymbol{\mu g} / \mathbf{m}^{\mathbf{3}} \mathbf{)}\end{array}\right.$ \\
\hline 1 & 2 & 3 \\
\hline 01.1 .2017 & 52.7 & 1.05 \\
\hline 04.1 .2017 & 129.8 & 2.60 \\
\hline 09.1 .2017 & 56.6 & 1.13 \\
\hline 10.1 .2017 & 97.5 & 1.95 \\
\hline 12.1 .2017 & 71.8 & 1.44 \\
\hline 13.1 .2017 & 83.2 & 1.66 \\
\hline 14.1 .2017 & 64.1 & 1.28 \\
\hline 15.1 .2017 & 103.4 & 2.07 \\
\hline 16.1 .2017 & 108.5 & 2.17 \\
\hline 20.1 .2017 & 61.4 & 1.23 \\
\hline 21.1 .2017 & 88.6 & 1.77 \\
\hline 22.1 .2017 & 128.8 & 2.58 \\
\hline 23.1 .2017 & 139.3 & 2.79 \\
\hline 24.1 .2017 & 135.2 & 2.70 \\
\hline 25.1 .2017 & 118.3 & 2.37 \\
\hline 26.1 .2017 & 87.4 & 1.75 \\
\hline 27.1 .2017 & 84.1 & 1.68 \\
\hline 31.1 .2017 & 125.8 & 2.52 \\
\hline & & \\
\hline & & \\
\hline
\end{tabular}

The days with registered exceedances of pollutant PM10 measured by the Vazrazhdane automatic measuring station in Ruse for January 2017 are according to data from the official bulletin for January 2017 of RIEW - Rousse [1]. They are presented in Table 1.

\subsection{Meteorological conditions for days with registered exceedances}

Data from Vazrazhdane automatic measuring station in Ruse for the period under consideration [4] are presented in Table 2. 
Due to the large number of exceedances registered over the period - 18 days with exceedances - for the purposes of the study, selected days were characterized by the highest ground dust concentrations. In order to capture all possible scenarios, the selected days for analysis are characterized by different daily average temperatures (from negative to positive) and by different direction of the predominant wind. Table 3 presents the selected days for the analysis.

Table 2. Meteorological conditions in the days with registered exceedances by pollutant PM10 by automatic station "Vazrazhdane" for January 2017.

\begin{tabular}{|c|c|c|c|}
\hline \multirow{2}{*}{ Date } & $\begin{array}{c}\text { Average } \\
\text { temperature }\end{array}$ & \multirow{2}{*}{$\begin{array}{c}\text { Predominant } \\
\text { wind direction }\end{array}$} & $\begin{array}{c}\text { Average speed of } \\
\text { the prevailing } \\
\text { wind }\end{array}$ \\
\cline { 2 - 2 } & {$\left[{ }^{\circ} \mathbf{C}\right]$} & & {$[\mathbf{m} / \mathbf{s}]$} \\
\hline 1 & 2 & 3 & 4 \\
\hline 01.1 .2017 & -0.25 & SW & 2.17 \\
\hline 04.1 .2017 & 1.35 & SW & 1.60 \\
\hline 09.1 .2017 & -9.52 & SE & 1.35 \\
\hline 10.1 .2017 & -11.46 & W & 0.92 \\
\hline 12.1 .2017 & -6.19 & SW & 1.88 \\
\hline 13.1 .2017 & 0.54 & SE & 0.66 \\
\hline 14.1 .2017 & 0.59 & SW & 2.03 \\
\hline 15.1 .2017 & -1.09 & SW & 1.36 \\
\hline 16.1 .2017 & -6.80 & E & 1.48 \\
\hline 20.1 .2017 & -5.74 & SW & 1.47 \\
\hline 21.1 .2017 & -6.67 & SW & 1.16 \\
\hline 22.1 .2017 & -4.04 & NW & 0.55 \\
\hline 23.1 .2017 & 0.23 & NE & 0.61 \\
\hline 24.1 .2017 & -1.91 & SW & 1.15 \\
\hline 25.1 .2017 & -3.03 & SW & 0.98 \\
\hline 26.1 .2017 & -2.68 & $\mathrm{E}$ & 1.25 \\
\hline 27.1 .2017 & -6.28 & SW & 1.38 \\
\hline 31.1 .2017 & -2.06 & SW & 0.44 \\
\hline
\end{tabular}

To obtain the necessary inputs for the software used PLUME for simulating the average daily concentrations of the PM10 pollutant tested for the selected overdrive days (Table 3), the hourly wind data from the AMS "Vazrazhdane" [4] were used. The resulting wind roses for each of the chosen days are shown on Figures $2-6$.

Table 3. Days with overheads with typical weather conditions.

\begin{tabular}{|c|c|c|c|}
\hline Date & $\begin{array}{c}\text { Average } \\
\text { temperature }\end{array}$ & $\begin{array}{c}\text { Predominant } \\
\text { wind } \\
\text { direction }\end{array}$ & $\begin{array}{c}\text { Average } \\
\text { speed of the } \\
\text { prevailing } \\
\text { wind }\end{array}$ \\
\cline { 2 - 2 } & {$\left[{ }^{\circ} \mathbf{C}\right]$} & & {$[\mathbf{m} / \mathbf{s}]$} \\
\hline 1 & 2 & 3 & 4 \\
\hline $01.1 .2017 \Gamma$. & -0.25 & $\mathrm{SW}$ & 2.17 \\
\hline
\end{tabular}




\begin{tabular}{|c|c|c|c|}
\hline 09.1 .2017 г. & -9.52 & SE & 1.35 \\
\hline 10.1 .2017 г. & -11.46 & $\mathrm{~W}$ & 0.92 \\
\hline 16.1 .2017 г. & -6.80 & $\mathrm{E}$ & 1.48 \\
\hline 22.1 .2017 г. & -4.04 & $\mathrm{NW}$ & 0.55 \\
\hline 23.1 .2017 г. & 0.23 & $\mathrm{NE}$ & 0.61 \\
\hline
\end{tabular}

Rose wind 01-01-2017

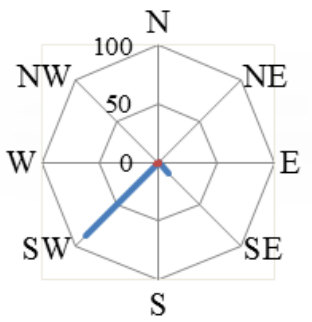

- wind frequency, $\%$

wind speed, $\mathrm{m} / \mathrm{s}$

Fig. 2. Rose of the wind on 01.01.2017.

Jan. 1, 2017 is characterized by strong southwest wind (87.5\% frequency), changing at the end of the day to southeast. The wind this day is at a low, almost zero average speed.

\section{Rose wind - 09-01-2017}

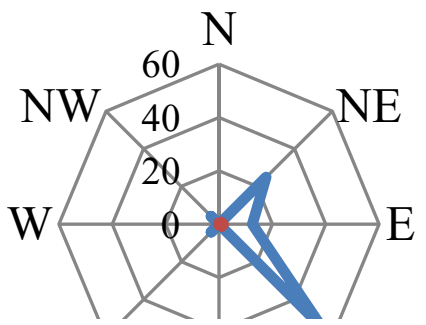

Fig. 3. Rose of the wind on 09.01.2017.

For the 9th of January, 2017 the southeast wind $(54.16 \%)$ is most pronounced, alternating with the east $(12.5 \%)$. The wind this day is at a low average speed.

\section{Rose wind 10-01-2017}

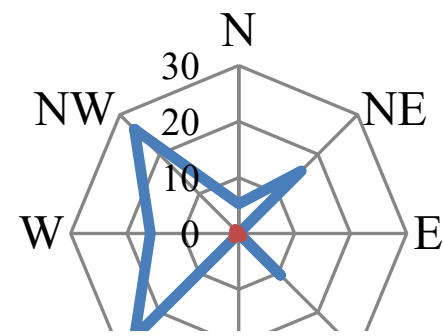

Fig. 4. Wind rose for 10.01.2017.

On January 10, Southwest and Northwest winds (26.32\%) were most pronounced, with a sharp shift in direction. Again the winds are at low average speed. 


\section{Rose wind 16-10-2017}

Fig. 5. Wind rose for 16.01.2017.

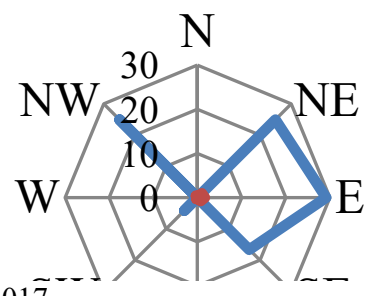

On January 16 Northwest and Northwest winds (25\% frequency) were most pronounced, a sharp shift was observed. Again the winds are at low average speed.

\section{Rose wind 22-01-2017}

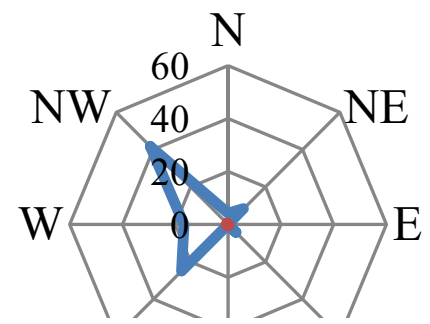

Fig. 6. Rose of the wind for 22.01.2017.

On 22 January, Northwest Wind (41.7\%) was most pronounced. Winds throughout the day have very low average speeds (the highest value is $0.67 \mathrm{~m} / \mathrm{s}$ for the southwest wind).

\section{Rose wind 23-01-2017}

Fig. 7. Rose of the wind for 23.01.2017.

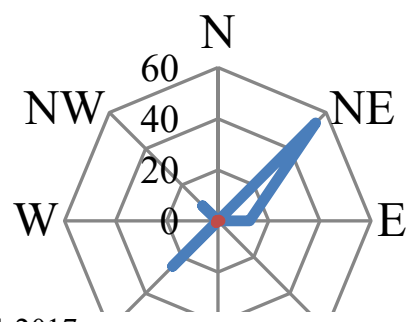

On 23 January the northeast wind was most pronounced (54.2\% frequency). Again the winds are at low average speed

\subsection{Identification of the dust sources in the industrial zone of Ruse}

The firms working on the territory of the industrial zone Ruse, from whose activity dust is emitted are presented in Table 4. 
Table 4. Organized sources of dust emissions in the ambient air [2, 3] from Industrial zone, Ruse.

\begin{tabular}{|c|c|c|c|}
\hline FIRMS & Activity & Source & $\begin{array}{c}\text { Number of } \\
\text { emitimg } \\
\text { devices; }\end{array}$ \\
\hline 1 & 2 & 3 & 4 \\
\hline $\begin{array}{c}\text { TM } \\
\text { Technology } \\
\text { JSC }\end{array}$ & $\begin{array}{c}\text { Manufacture of metal } \\
\text { products }\end{array}$ & Shot blasting machine & 1 \\
\hline $\begin{array}{c}\text { Ecogalvanic } \\
\text { LTD }\end{array}$ & $\begin{array}{c}\text { Application of surface } \\
\text { decorative and corrosion } \\
\text { resistant coatings of } \\
\text { metals }\end{array}$ & $\begin{array}{c}\text { Local aspiration to } \\
\text { production capacities }\end{array}$ & 2 \\
\hline $\begin{array}{c}\text { Fibran, } \\
\text { Bulgaria JSC } \\
\text { Oleo protein } \\
\text { LTD }\end{array}$ & $\begin{array}{c}\text { Production of insulating } \\
\text { materials }\end{array}$ & $\begin{array}{c}\text { Fuel source, plant for } \\
\text { fiber production }\end{array}$ & 2 \\
\hline $\begin{array}{c}\text { Oberosterreich } \\
\text { ische } \\
\text { viodiesel }\end{array}$ & $\begin{array}{c}\text { Production of raw } \\
\text { Bulgaria LTD }\end{array}$ & $\begin{array}{c}\text { Local aspiration to } \\
\text { machines }\end{array}$ & 18 \\
\hline
\end{tabular}

\subsection{Computer simulation}

Computer simulation aimed to calculate the maximum ground PM10 concentrations emitted by the group of industrial sources considered (Table 4) and to calculate the distances to which PM10 air pollutant would be distributed is provided.

A computer simulation was performed to determine the average daily concentration of PM10 of days with exceedances (Table 3) using the established software program PLUME [6].

The program product has limitations on the number of leakages that are entered as incoming data. To avoid the constraint, virtual drives have been created by merging several real chimneys.

The atmosphere area under consideration is presented as coordinate network $(\mathrm{x}, \mathrm{y})$ having parameters $16000 \times 16000 \mathrm{~m}$ or 32 steps $* 500 \mathrm{~m}$. The model is made with a type of underlying surface "urban area". The industrial zone is located in the regulation boundaries of the town of Rousse.

Input data on weather conditions used are winds for the current day and average daily temperature for that day.

The spread of dust from the territory of the industrial zone of Ruse on January 1, 2017 is presented in Fig. 8 . 


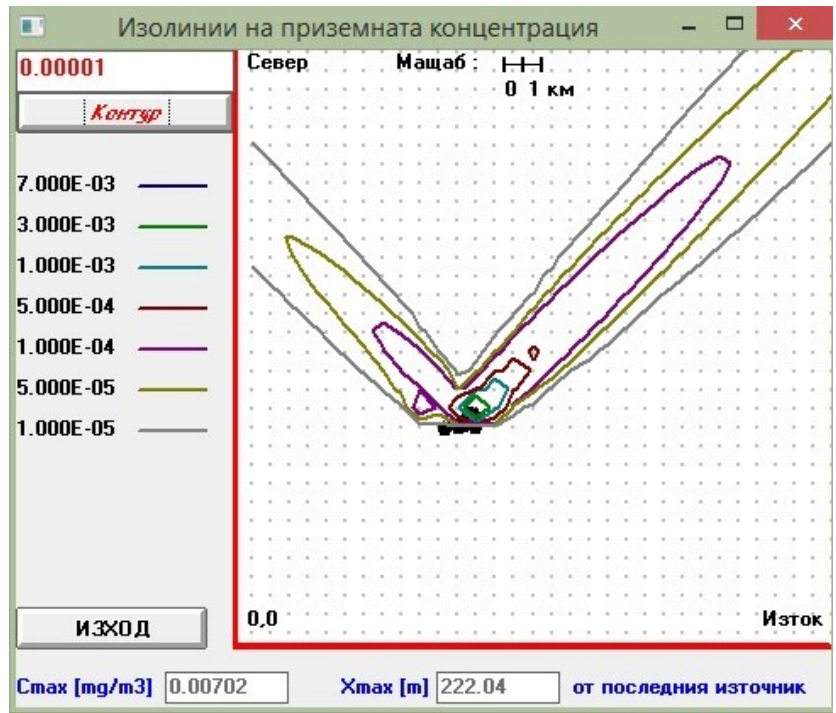

Fig. 8. Isolines of the daily average dust concentrations on January 1, 2017 from the territory of the industrial zone - Ruse.

The spreading of dust from the territory of the industrial zone - Ruse on January 9, 2017 is presented in Fig. 9.

The spreading of dust from the territory of the industrial zone - Ruse on 10 January 2017 is presented in Fig. 10.

The spread of dust from the territory of the industrial zone - Ruse on January 16, 2017 is presented in Fig. 11.

The spread of dust from the territory of the industrial zone - Ruse on 22 January 2017 is presented in Fig. 12.

The spread of dust from the territory of industrial zone - Ruse on January 23, 2017 is presented in Fig. 13.

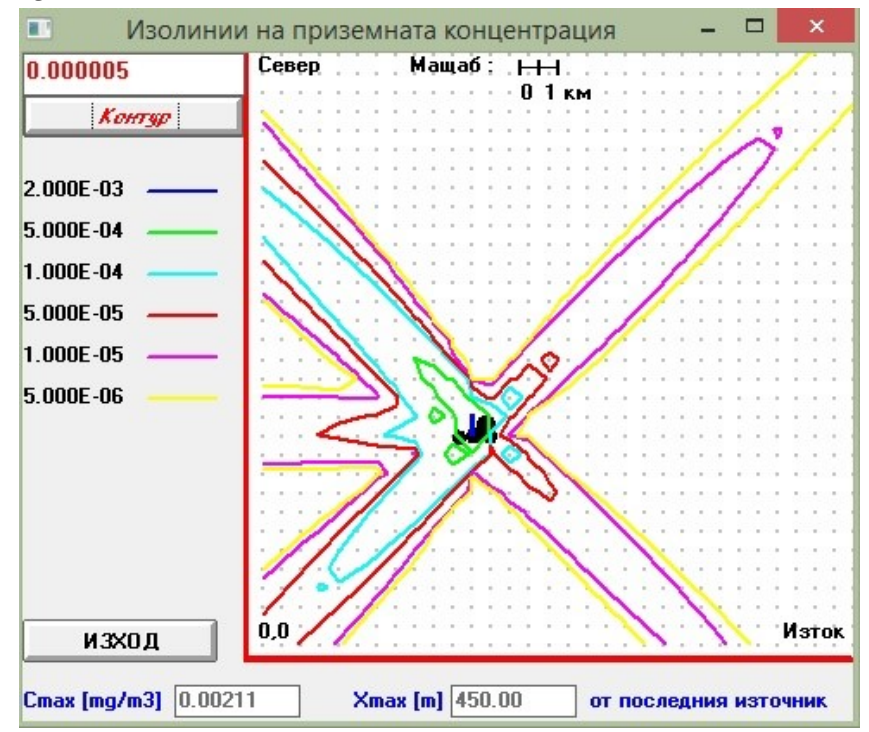

Fig. 9. Isolines of maximum daily average dust concentrations on January 09,2017 from the territory of the industrial zone - Ruse. 


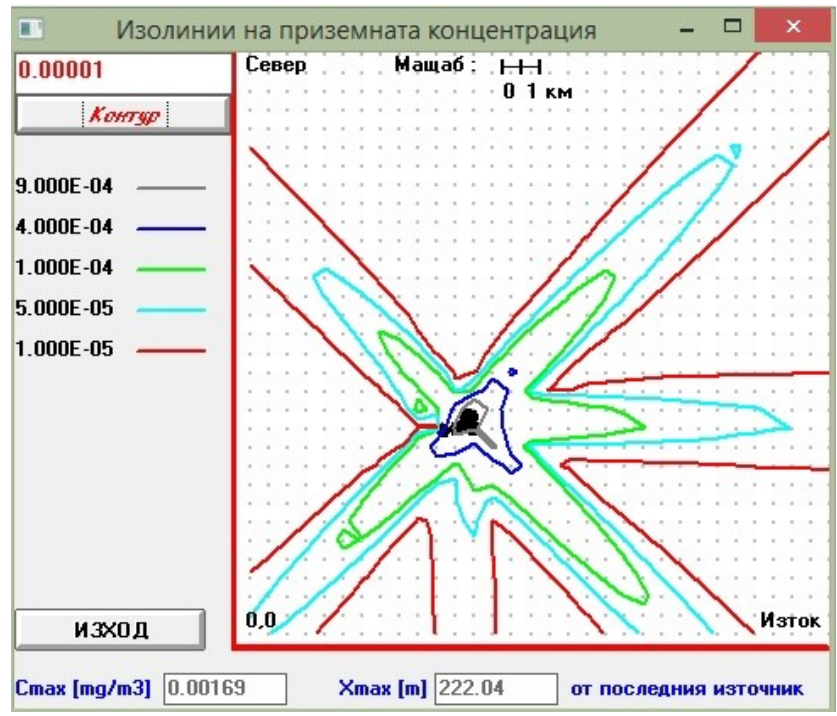

Fig. 10. Isolines of daily average dust concentrations on 10 January 2017 from the territory of the industrial zone - Ruse.

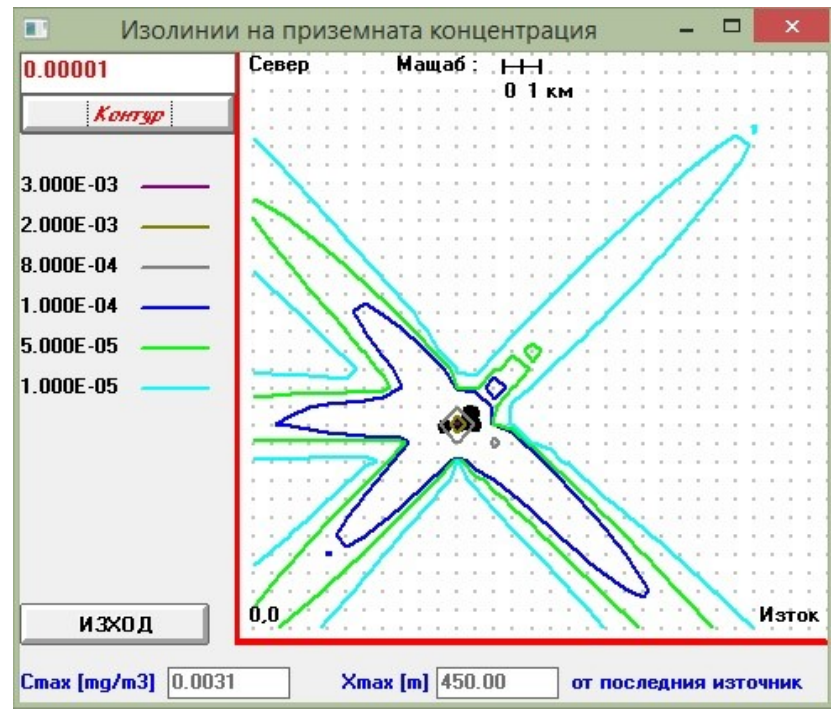

Fig. 11. Isolines of daily average concentrations of dust on January 16, 2017 from the territory of the industrial zone - Ruse. 


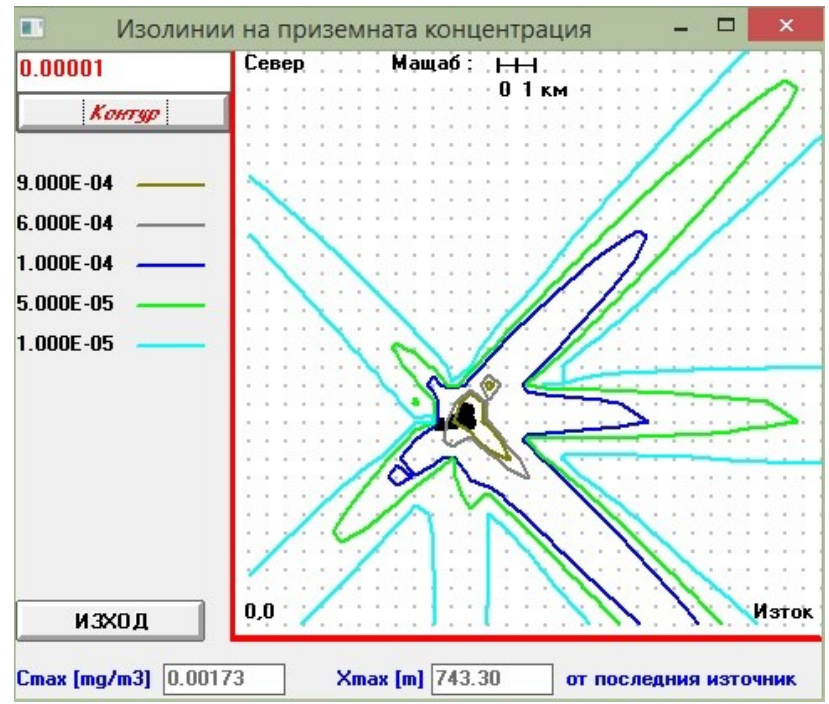

Fig. 12. Isolines of daily average dust concentrations on 22 January 2017 from the territory of the industrial zone - Ruse.

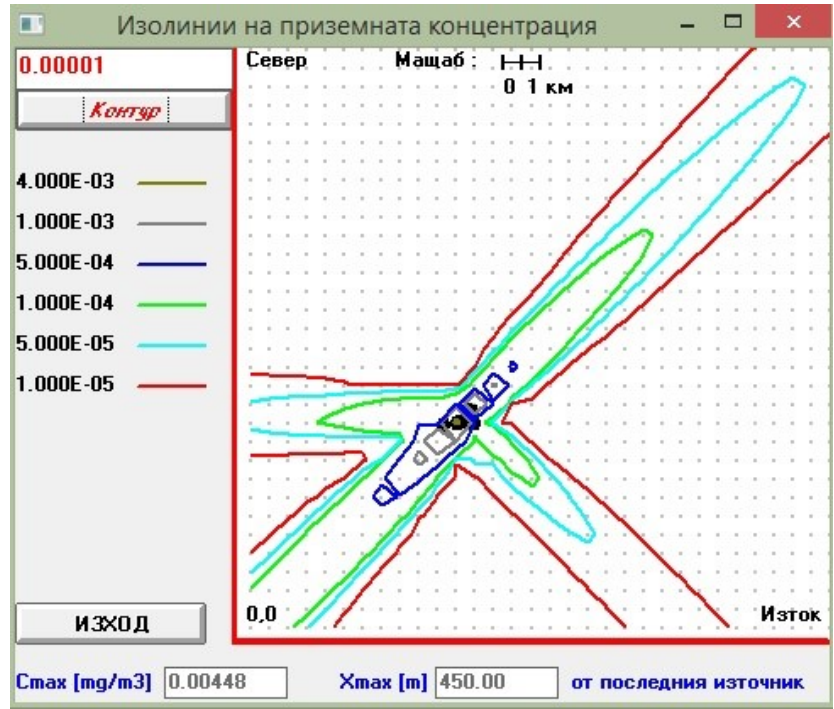

Fig. 13. Isolines of daily average concentrations of dust on 23 January 2017 from the territory of the industrial zone - Ruse.

\subsection{Analysis of the values of the ground concentration of dust reaching the territory of the Republic of Romania and the possibility of their impact on the air quality in the cross-border area}

The Romanian bank of the River Danube in this area of the river is 910 meters away (see Fig.1). The Romanian town of Giurgiu is situated in the northwest direction of $6,100 \mathrm{~km}$ and town Comaska, the county of Comasca, to the north of 4,400 km. 
Table 5 Values of PM10 ground concentrations reaching to Romania

\begin{tabular}{|c|l|l|l|l|l|l|}
\hline \multirow{2}{*}{ Date } & \multicolumn{2}{|c|}{$\begin{array}{c}\text { Danube river } \\
\text { coast, Romania }\end{array}$} & \multicolumn{2}{|c|}{ Gurgue, Romania } & \multicolumn{2}{c|}{$\begin{array}{c}\text { Comanska, } \\
\text { Romania }\end{array}$} \\
\cline { 2 - 7 } & SDC & MEK & SDC & MEK & SDC & MEK \\
\cline { 2 - 7 } & $\mathrm{mg} / \mathrm{m}^{3}$ & $\mathrm{mg} / \mathrm{m}^{3}$ & $\mathrm{mg} / \mathrm{m}^{3}$ & $\mathrm{mg} / \mathrm{m}^{3}$ & $\mathrm{mg} / \mathrm{m}^{3}$ & $\mathrm{mg} / \mathrm{m}^{3}$ \\
\hline $01 / 01 / 2017$ & $5 \mathrm{E}-05$ & $5 \mathrm{E}-05$ & $1 \mathrm{E}-05$ & $>1 \mathrm{E}-05$ & $1 \mathrm{E}-04$ & $1 \mathrm{E}-05$ \\
\hline $09 / 01 / 2017$ & $5 \mathrm{E}-05$ & $1 \mathrm{E}-04$ & $1 \mathrm{E}-04$ & $1 \mathrm{E}-05$ & $1 \mathrm{E}-05$ & $>1 \mathrm{E}-05$ \\
\hline $10 / 01 / 2017$ & $1 \mathrm{E}-04$ & $5 \mathrm{E}-05$ & $1 \mathrm{E}-05$ & $>1 \mathrm{E}-05$ & $5 \mathrm{E}-05$ & $>1 \mathrm{E}-05$ \\
\hline $16 / 01 / 2017$ & $1 \mathrm{E}-04$ & $1 \mathrm{E}-04$ & $1 \mathrm{E}-05$ & $>1 \mathrm{E}-05$ & $5 \mathrm{E}-05$ & $>1 \mathrm{E}-05$ \\
\hline $22 / 01 / 2017$ & $1 \mathrm{E}-05$ & $1 \mathrm{E}-06$ & $1 \mathrm{E}-05$ & $>1 \mathrm{E}-06$ & $1 \mathrm{E}-04$ & $>1 \mathrm{E}-06$ \\
\hline $23 / 01 / 2017$ & $1 \mathrm{E}-03$ & $1 \mathrm{E}-07$ & $1 \mathrm{E}-05$ & $>1 \mathrm{E}-07$ & $1 \mathrm{E}-04$ & $>1 \mathrm{E}-07$ \\
\hline
\end{tabular}

* SDC - average daily PM10 concentration, MEK - maximum PM10 concentration

The results of the computer simulation of the ground concentrations reaching the receptor points on the territory of Rumania are presented in tabular form - Table 5.

To study the possible maximal single concentrations (MEK) reaching the receptors one wind direction simulation (predominant for the day) was conducted. The results are shown in Fig. $14 \div 19$.

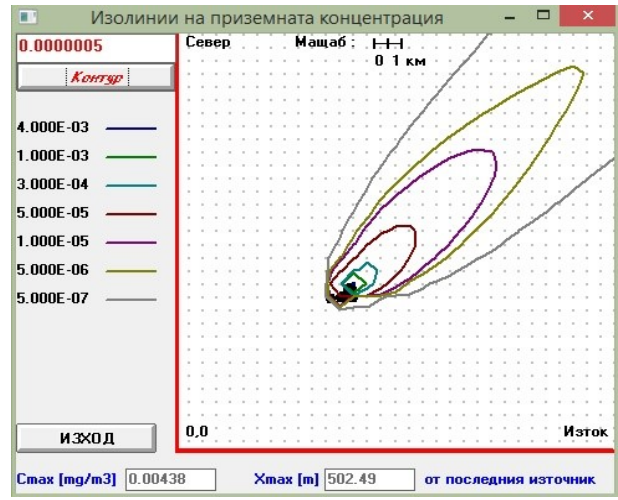

Fig. 14. MEK for 01 Jan. 2017.

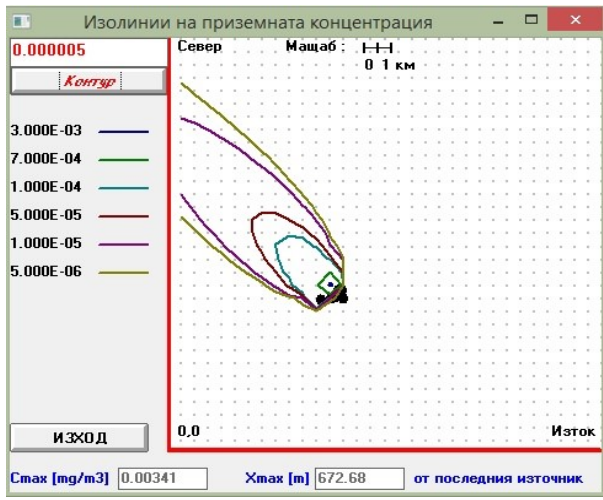

Fig. 15. MEK for 09 Jan. 2017. 


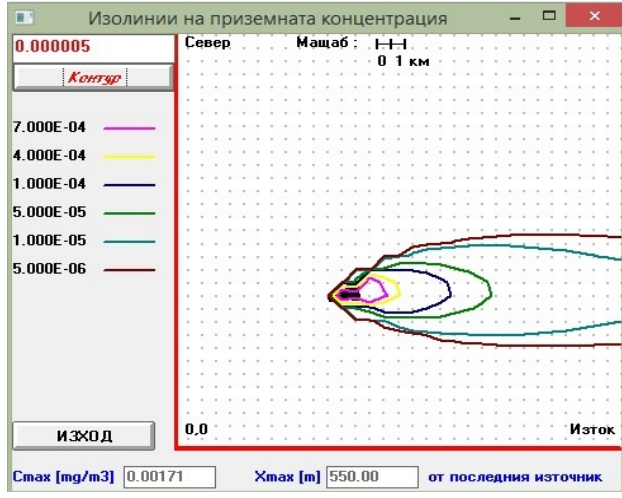

Fig. 16. MEK for 10 Jan. 2017.

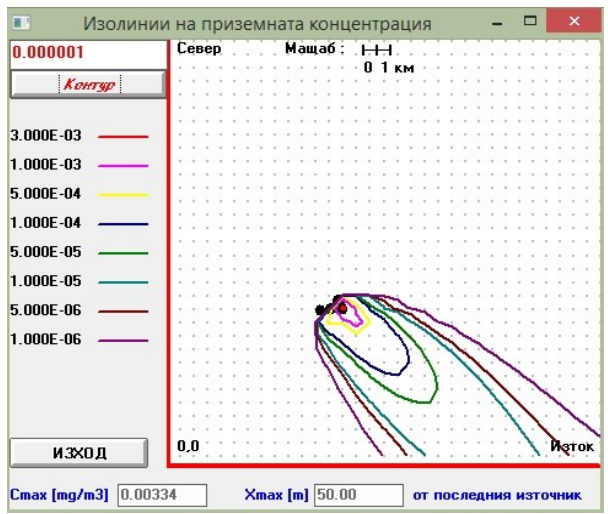

Fig. 18. MEK for 22 Jan. 2017.

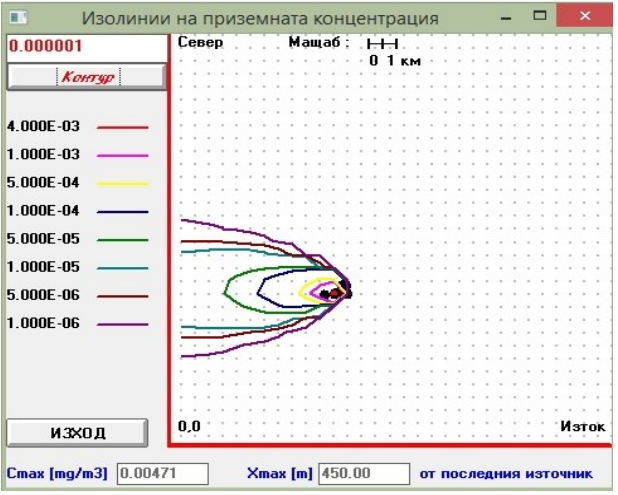

Fig. 17. MEK for 16 Jan. 2017.

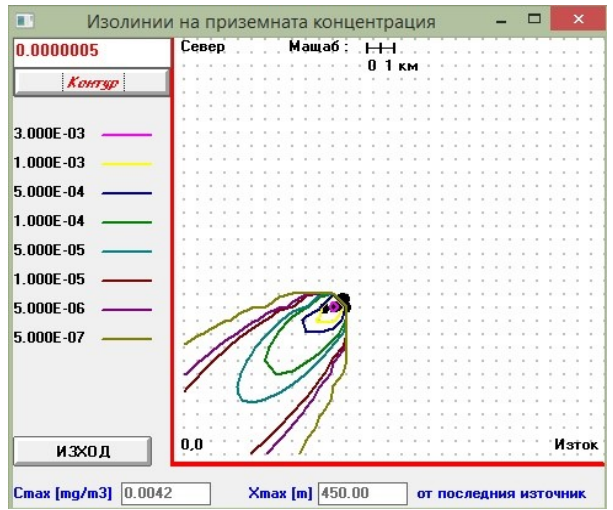

Fig. 19. MEK for 23 Jan. 2017.

The established daily norm for the protection of human health for PM10 is $50 \mu \mathrm{g} / \mathrm{m}^{3}$. The ground concentrations of the pollutant reaching the Romanian territory represent only 2 $\div 0.02 \%$ of this norm. They have no potential for disturbing the quality of the ambient air in the area.

\section{Conclusions}

The survey conducted is limited in time, the representative monthly sample of January 2017 is considered.

Despite the limitation, it is established that the operation of the installations located on the territory Industrial zone - Ruse has no potential for cross-border PM10 contamination of the atmospheric air in the $\mathrm{BG}-\mathrm{RO}$ cross - border area.

Acknowledgments to the employees of the Regional Inspectorate of Environment and Water Rousse and the environmentalists of Oleo Protein LTD and Fibran Bulgaria JSC for providing the complete information necessary for the input data of this analysis.

\section{References}

1. Data on the measured concentrations of PM10 at the monitoring stations on the territory of the RIEW - Rousse in January 2017,

http://www.riosv-ruse.org/mesechna-spravka-za-nivata-na-fpch10.html 
2. Reports of own periodic measurements of " Ecogalvanic" LTD, "Oleo Protein" LTD, "Fibran Bulgaria" JSC, "TM Tehnologi" JSC, provided by RIEW-Rousse with Decision for access to public information 329/2017

3. Reports of Own Periodic Measurements of "Oleo Protein" LTD and "Oberosterreichische Biodiesel Bulgaria" LTD, provided by the legal entities.

4. Hourly meteorological report for Rousse, January 2017, provided by the decision for access to public information 330/2017

5. Publicly available map material on the official site of the Agency for Geodesy, Cartography and Cadastre, http://www.cadastre.bg/

6. Methodology for calculation of leakage height, dispersion and expected concentrations of pollutants in the ground layer of 25 February 1998, adopted by the Ministry of Environment and Waters, the Ministry of Regional Development and Public Works and the Ministry of Health, http://www5.moew.government.bg/

7. I. Zheleva, E. Veleva, M. Filipova, AMiTaNS, 2017 (in print) 